\title{
A DOUTRINA COSMOLÓGICO/SOTERIOLÓGICA ONTOLÓGICO/MATERIALISTA DUALISTA MANIQUÉ́STA
}

\author{
Dr. Marcos Roberto Nunes Costa ${ }^{1}$ \\ Universidade Cáólica de Pernambuco (UNICAP)
}

\begin{abstract}
RESUMO
Fundado na Ásia, no século III, por Mani, o maniqueísmo se constituía, do ponto de vista doutrinal, numa gnose que misturava princípios das seitas/religiões orientais, especialmente do Zoroastrismo e do Budismo, da Filosofia Grego-Romana e do Cristianismo. Sua tese fundamental consistia na afirmação de dois princípios ontológicos do mundo: o Bem ou a Luz, representado no sol, e o Mal ou as Trevas, personificado na matéria. Desse dualismo ontológico nascia uma cosmologia/soteriologia que apresentava a história da salvação do mundo em três tempos: o primeiro, inicial, engloba as origens cósmicas dos dois princípios e seus primeiros afrontamentos. O segundo, médio, é o tempo da mistura entre os dois Reinos, que se caracteriza pela queda de uma parte da Luz na matéria, bem como, é o tempo da criação dos seres no universo. Enfim, o terceiro, final, marca a libertação de todas as partículas da Luz imbricadas na matéria, com o retorno da Luz ao reino do Pai e a queda definitiva da matéria no inferno.
\end{abstract}

Palavras-chave: Maniqueísmo, Cosmologia, Soteriologia, Dualismo, Bem, Mal.

\begin{abstract}
Founded in Ásia, in the third century, by Mani, manicheism constituted, by itself, in a doctrinal viewpoint, in a gnosis that mixed oriental principles of sects/religions, specially from Zoroastrism and Budism, Greek-Roman Philosophy and Christianism. His basic thesis consisted of statement of two ontological principles: Good or Light, presented by the sun, and Evil or Darkness, personified in matter. From this ontological Dualism arose a cosmology/soteriology that presented the salvation history of world in three moments: the first-one, initial, embodies the two principles cosmic origins and their first conflicts. The second-one, medial, is the mixture time is characterized by the downfall of one the Light parts in the matter, as well as it is the universe being creation time. At last, the third-one, final, marks the liberation of all Light particles, imbricated in the matter, meaning the Light return to Father's kingdom and the matter's definitive downfall into the hell.
\end{abstract}

Key words: Manicheism, Cosmology, Soteriology, Dualism, Good, Evil.

\section{MANI E AS ORIGENS HISTÓRICAS DO MANIQUEÍSMO}

O maniqueísmo foi fundado por Mani, um monge asceta que nasceu em 14 de abril de 216 d. C., na aldeia rural de Nahar-Koutha, distrito de Mardinu, localizada entre os rios Eufrates e Tigre (não muito distante da atual Bagdad), na Babilônia do Norte) ${ }^{2}$.

1 Professor de Filosofia Patrístico/Medieval da UNICAP e do INSAF-Recife-Brasil, Líder do Grupo de Estudos e Pesquisas em Filosofia Antiga e Medieval-GEPFAM/UNICAP/CNPQ, Presidente da Comissão Brasileira de Filosofia Medieval-CBFM.

2 Cf. TARDIEU, [s.d.], p. 5. Informações igualmente confirmadas por RIES, 1980. p. 199. 
Segundo alguns comentadores, os maniqueus embelezaram a história de Mani fazendo uma analogia com a história de Jesus Cristo, uma vez que consideravam Mani como o enviado, o profeta anunciado por Cristo. Assim sendo, ao seu pai, Pattig (ou Patteg), deram uma descendência nobre, como fazendo parte da linhagem dos Arsácides, a exemplo de José que era proclamado como descendente da antiga família real de Israel, conforme narra Polotsky:

Mani, enquanto babilônico, era súdito do império persiano; na realidade, ele era também de origem irânica: por parte de sua mãe e provavelmente também por parte do pai ele era aparentado com a família da casa real dos Arsácides ${ }^{3}$.

Igualmente, por analogia cristianizante, segundo Michel Tardieu, deram à mãe de Mani o nome da mãe de Jesus: Maryam ${ }^{4}$. Bem como, à semelhança das narrações da infância de Jesus, onde constam a partida do casal José e Maria de Nazaré para Jerusalém, e dali para o Egito, os pais de Mani teriam emigrado de Hamadam para al-Madaín, e dali para Nahr-Kuthi. Por fim, uma outra semelhança, é que, a exemplo de Jesus, pelo menos para o catolicismo, Mani é filho único.

Ainda segundo Michel Tardieu ${ }^{5}$, seguindo a enciclopédia árabe de Ibn al-Nadim, durante o tempo em que esteve em al-Madaín, o pai de Mani, Pattig, freqüentava uma casa de ídolos, provavelmente dos Sabeus, onde imperavam práticas licenciosas. Porém, um certo dia, este ouviu uma voz que o ordenava a abster-se de carnes, vinhos e a seguir uma rigorosa continência sexual.

A aparição se repetiu por três vezes até que, um certo dia, este resolveu seguir a ordem e mudou de religião, juntando-se a um grupo dos helxassaítas, que segundo Daniel-Rops,

eram discípulos dum certo Helxassai ou Aleixo, que, no reinado de Trajano, pretendeu ter recebido, dum anjo com a altura de cem quilômetros, a revelação duma doutrina estranha, em que se ligam, na mais extraordinária amálgama, práticas judaicas, dogmas cristãos e práticas da magia ${ }^{6}$.

Entretanto, só aos quatro anos de idade, seu pai o levou para morar com ele na comunidade dos helxassaítas, onde, segundo Puech, entrou, pela primeira vez, em contato com os princípios gnósticos e cristãos que essa seita comportava os quais, mais tarde, vão influenciar na formação de sua nova religião:

Em uma comunidade desse tipo onde, creio, formou seu pensamento e amadureceu sua vocação, devemos considerar que o Cristianismo —ou ao menos, uma certa imagem de Cristo e dos ensinamentos evangélicos- exerceu, desde o princípio, se não decisiva, ao menos profunda influência sobre Mani ${ }^{7}$.

Na idade de 12 anos, em 01 de abril de 228 d. C. Mani foi visitado pela primeira vez por um anjo mensageiro do Reino da luz que lhe anunciou as primeiras Boas Novas de sua futura e nova religião.

Mas como Mani era ainda muito novo, após a primeira aparição do anjo mensageiro esté permaneceu entre os helxassaítas, apesar de já ter começado a manifestar seu descontentamento

3 POLOTSKY, 1996. p. 26. Já PUECH, 1988, p. 169, diz: «Parece que ele pertencesse, se não da parte do pai (Pati, Pattichios, Patecio) ele mesmo originário de Hamadãn (antiga Ecbatana), ao menos da parte materna (Maryam?), a uma família principesca, aparentada com a dinastia dos Arsacides».

\footnotetext{
4 Maryam para TARDIEU, [s.d], p. 7, e RIES, 1980, p. 1999 e Marjan para PETERSON, 1951, p. 1959.

5. Cf. TARDIEU, [s.d.], p. 8.

6 DANIEL-ROPS, 1960 , p. 60.

7 PUECH, 1979, p. 205.
} 
para com estes, levando-o, inclusive, a ser acusado de apóstata, por estar preparando uma nova religião.

Aqui, mais uma vez, para Michel Tardieu, o intervalo entre a primeira e a segunda aparição do anjo mensageiro, que se caracteriza pelo período de amadurecimento de Mani para assumir a missão, é mais uma alusão à vida de Jesus, pois,

da mesma forma que Mani-menino copiava Jesus-menino, o jovem Mani discutindo com as autoridades da sua comunidade imita o Jesus das controvérsias anti-judaizantes referidas pelos Sinópticos 8 .

Finalmente, doze anos após a primeira aparição, o mesmo anjo mensageiro reapareceu a Mani e revélou-lhe os mistérios insondáveis e lhe deu ordens de proclamar a verdade divina.

Dois anos depois da segunda aparição do anjo, em 242, com 26 anos de idade, Mani tomou consciência de sua missão e começou a anunciar a nova fé.

Pouco tempo depois de iniciar sua missão, Mani foi expulso de sua terra natal. A partir de então, percorreu vários países, tendo propagado sua religião por toda a Ásia, na Índia e, finalmente, na China, onde conviveu por dez anos, entrado em contato com algumas religiões orientais, como, por exemplo, o budismo, as quais teriam grande influência em seu pensamento

Trinta anos depois de ter sido expulso de sua terra natal, em 272, mudou o contexto político e Mani foi convidado a retornar à Babilonia pelos seus adeptos, que lhe prometiam melhores dias. Mas, dois anos depois, mudou novamente o contexto político e o novo Rei, Bahrâm I, iniciou uma campanha de caça e perseguições aos maniqueístas. Finalmente, em 277, Mani foi encarcerado na cidade de Gundêshâhpúr, na Susiana, e, depois de 26 dias de prisão, seguindo a tradição, crucificado e esfolado, provavelmente em 26 de fevereiro de $277^{9}$, com sessenta e um anos de idade, tendo sua pele exposta em um templo dos arianos ${ }^{10}$.

Aqui, mais uma vez, J. P. Asmussen, nos alerta que, a exemplo dos demais dados da vida de Mani, os maniqueus, por processo cristianizante, descreveram o martírio e crucificação de Mani a exemplo da morte de Cristo, quando diz:

Sem dúvida, a crucificação de Mani, de que falam seus discípulos, é uma assemelhação deliberada à morte de Cristo, o que vem confirmar a importância de Jesus para o sisstema maniqueu. Se Cristo, o doador por excelência da gnose, morreu na cruz, Mani, a maior personalidade entre todos os redentores, tinha que sofrer o mesmo destino ${ }^{11}$.

Porém, sua seita não morreu com ele; Mani, diferentemente de Buda, Zoroastro e Jesus Cristo, que não escreveram nada, deixou alguns escritos, comumente chamados de Escrituras

\section{TARDIEU, [s.d], p. 20.}

9 PUECH, 1988, p. 174, diż haver grande controvérsia acerca da data da tal «crucificação» de Mani. Segundo este, o historiador. W.B. Henning, afirma ter sido entre os dias 14 de fevereiro e 2 de março de 274. H.H. Schaeder, por sua vez, a coloca entre o dia 19 de janeiro e 14 de fevereiro de 276 e, finalmente, S. H. Taqizadeh, a transfere para o dia 26 de fevereiro de 277.

10 Cf. DANIEL-ROPS, 1960, p. 566 e HAARDT, 1984, p. 417. Já RIES, 1980, p. 200, diz que «eles decapitaram seu corpo e expuseram sua cabeça nas portas da cidade, no ano de 277». BARDY, 1926, p. 1864, por sua vez, diz que «ele foi esfolado, decapitado, empalhado e enviado a Dschoundisbour, a nova capital dos reis da Pérsia, no ano de 277». Já VANNINI, 1989. p. 20, diz que «depois de uma 'paixão' de vinte e seis dias, que os maniqueus chamam pelo termo cristão de 'crucificação', morreu Mani em 27 de fevereiro de 277; seu corpo foi jogado aos cães e seus seguidores perseguidos, mas apesar disto, o maniqueismo se propagou rapidamente do Mediterrâneo até a China».

11 ASMUSSEN, 1973, p. 571. Da mesma opinião é LISSÓN, 1984. p. 869, comentado a crucificação de Mani, diz: «Os discípulos falam da crucificação de Mani, mas não passa de uma alusão à crucificação de Cristo, com testemunho de seu martírio, mas não é verdade que seja um fato histórico» e PUECH, 1990, p. 437: «Os 26 dias de sofrimento no cárcere e crucificação de Mani não passam de uma alusão à paixão e morte de Cristo. Igualmente, diz HAARDT, 1984, p. 418: «A morte de Mani é denominada, com apoio na paixão de Cristo, crucificação». 
Maniquéias ou Cânon Oficial que deveria ser seguido pelos membros de sua Igreja e uma grande quantidade de discípulos. Em pouco tempo, a nova religião propagou-se rapidamente não só na Ásia, mas também na Europa, desde a Dalmácia até à Espanha, e na África ${ }^{12}$.

\section{A DOUTRINA COSMOLÓGICO/SOTERIOLÓGICA DUALISTA MANIQUÉIA}

Os maniqueus estavam preocupados em responder a uma simples pergunta: como é possível compatibilizar os males presentes no mundo: as injustiças, as desgraças, os ódios, as pestes, as calamidades, as misérias dos homens, os defeitos das sociedades, e muitas outras, com a bondade de Deus? Ou seja, Deus-o Bem, pode ser causa do mal? ou devemos admitir a um outro ser, tão poderoso quanto Ele, a causa do mal?

Essa preocupação maniquéia em achar uma resposta que, ao mesmo tempo, resolvesse o problema do mal e salvasse a incorruptibilidade de Deus, encontramos claramente, em uma passagem das Confissões, onde santo Agostinho, referindo-se ao tempo em que esteve envolvido com o maniqueísmo, diz:

Com efeito, quando meu espírito se esforçava por voltar à fé católica, sentia-se repelido, porque a opinião que formava da fé católica não era exata [...]. Parecia-me injusto crer que não tivésseis criado nenhum mal do que acreditar que proviesse de Vós a sua natureza tal qual eu imaginava. Com efeito, o mal aparecia à minha ignorância, não só como substância mas como substância corpórea, já que a minha mente não podia formular a idéia senão de um corpo sutil, difundido pelo espaço [...]. Daqui deduzia eu a existência de uma certa substância do mal que tinha a sua massa feia e disforme - ou fosse grosseira como a que chamam terra ou tênue e sutil como o ar- a qual eu julgava ser o espírito maligno investindo a terra. E porque a minha piedade, como quer que ela fosse, me obrigava a crer que a bondade de Deus não criou nenhuma natureza má, estabelecia eu duas substâncias opostas a si mesmas, ambas infinitas: a do mal mais diminuta e a do bem mais extensa. Deste princípio pestilencial provinha as restantes blasfêmias (Conf., $\mathrm{V}, 10,20)^{13}$.

Tentando resolver tal dilema, os maniqueus vão construir uma doutrina ontológico-cosmológico-soteriológico-dualista que isenta Deus de toda responsabilidade pelos males existentes no universo, e o homem pelas maldades praticadas individualmente, a qual passaremos a apresentar.

\subsection{O primeiro tempo: a origem ontológica dos dois reinos}

O maniqueísmo começa sua doutrina anunciando a existência ontológica de dois princípios originantes: de dois mundos ou duas naturezas, conforme declara Agostinho, criticandoos, em o Sobre a Natureza do Bem:

12. Sobre a larga e rápida expansão do maniqueísmo ver, especialmente: RIES, 1980, p. 200-201; BARDY, 1926 , p. 1864 a 1872 e PUECH, 1990, p. 438-441. Maiores informações sobre a vida de Mani e a formação histórica do maniqueísmo, ver nossa obra: COSTA, 2003, especialmente o cap. 2, intitulado «Mani e as Origens Históricas do Maniqueísmo"), p. 25-38.

13 Igualmente, mais adiante, diz: «Donde me veio querer eu o mal e não querer o bem? Quem colocou e semeou em mim esta semente de amargura, se tudo quanto sou, foi criado por meu-Deus, que é suavíssimo? (Conf., VII, 3). Sobre os motivos que levaram Agostinho a abraçar o maniqqueísmo por cerca de nove anos e a rejeitá-lo e criticá-lo, mais tarde, depois de convertido ao cristianismo, ver nossas obras: COSTA, 1999. 215 p. e COSTA, 2003, 429 p. 
Se os maniqueus quisessem refletir, sem que um zelo funesto os levassem a defender o seu erro, e se temessem a Deus, não blasfemariam impiedosamente ensinando que há duas naturezas, uma boa, a que chamam de Deus, e outra má, não criada por Deus ( $D e$ nat. boni, I, 41) ${ }^{14}$,

ou seja, dois princípios ontológicos, e não dois deuses, conforme diz o bispo maniqueu Fausto, em debate com Agostinho:

É certo que confessamos dois princípios, mas a um chamamos de Deus e ao outro matéria (hylê), ou para utilizar uma expressão comum e freqüente, demônio (Contra Faust. man., XXI, 1) ${ }^{15}$.

O primeiro, o Reino da Luz, situado «no alto», é a casa do Pai da Grandeza, cidade da paz e de uma beleza incomparável, conforme narra Agostinho em o Contra a Epistola que os Maniqueus Chamam de Fundamento:

Sobre o primeiro império da Luz, domina Deus, o Pai, também chamado Pai da Luz, eterno por sua origem santa, magnífico no seu poder, verdadeiro por sua essência mesma, sempre feliz na sua própria eternidade, contendo em si a sabedoria e os sentidos da vida (Contra. ep. quam man. voc. fund., I, 13).

Apesar de parecer ser de natureza espiritual, ou ser assemelhado ao Deus do Cristianismo, o deus do maniqueísmo é totalmente diferente. Primeiro, ele é de natureza física, um ser corpóreo, que ocupa espaço, embora não tenha uma forma humana, finita e limitada, mas infinito e ilimitado.

Em decorrência disso (segundo), os maniqueus tinham uma concepção panteísta de deus, onde as suas emanações são da mesma substância dele, ou como diz J. P. Asmussen: «O Pai da grandeza se identifica com as suas emanações, do mesmo modo que estas são idênticas entre si» ${ }^{16}$.

«Abaixo» do Reino da Luz, ou seja,

ao lado desta terra ilustre e santa se encontra a terra das Trevas, profunda e imensamente grande, onde habitam os corpos ignorantes, raça pestífera. Lá se encontram as trevas infimas, emanadas do mesmo príncipe e vis como ele [...]. No seu interior sopram os ventos terriveis e violentos com seu príncipe. É a região corrompida pelo fogo com seus chefes e suas nações. No centro, encontra-se um país cheio de obscuridade e fumaça, onde demanda a soberania terrível deste mundo, rodeada de cinco príncipes, que com ele formam uma cabeça e um corpo único (Contra ep. quam man. voc. fund., I, 28).

Assim sendo, esse segundo reino - Reino das Trevas-é identificado no maniqueísmo com a noite, ou trevas: noite da matéria, do erro, da morte, da carne e do desejo. Seu nome próprio é a Matéria, Hylê.

Para os maniqueus esses dois reinos: o da Luz $\longrightarrow$ o Bem-e o das Trevas -o Mal一, são incriados, ou co-eternos: Com forme palavras de Puech:

No princípio do mito cosmológico, no 'Momento Inicial' ou 'Anterior', há uma dualidade radical e inteira de duas 'Naturezas', de duas 'Substâncias' ou 'Raizes': a Luz e as Tre-

14 Já, em outras obras antimaniquéias agostinianas, aparecem outras nomenclaturas, como, por exemplo, no Contra Fort. man. I, 14, Agostinho fala de «duas substâncias»; no De mor. Eccl. cath. et mor. man., II, 2,5, no Contra Felic. man. I, 17 e Contra ep. quam man. voc. fund. I, 13, de «dois reinos», e ainda no Contra Felic. man. I, 17, de «duas terras» ou «dois mundos»; no Contra Fort. man. I, 22, fala de «duas raizes».

15 GARCIA BAZAN, 1978, p. 238, chama a atenção de que os maniqueus não aceitam que se use o epíteto «Deus» para referir-se à matéria, apesar desta ser um princípio originante com poderes idênticos aos do Deus da Luz.

16 ASMUSSEN, 1973, p. 574. 
vas, o Bem e o Mal, Deus e a Matéria. Cada um desses é em si mesmo um 'Princípio', sendo incriados, autônomos, eternos; cada um de potência igual. Enfim, esses não têm nada em comum, mas se opõem em tudo ${ }^{17}$.

Igualmente, por terem princípios idênticos e independentes, cada um tem idêntica potência. Assim, por exemplo, ambos têm poder de criar, ou melhor de emanar, e na luta cósmica medem forças em pé de igualdade.

\subsection{O tempo médio: as criações ou emanações}

O tempo médio, por sua vez, é dividido em três momentos:

\subsubsection{Primeiro momento: o Homem Primordial}

Segundo o mito maniqueu, os dois Reinos nada conheciam um do outro, até que, um dia (atemporalmente), o príncipe das Trevas viu o espetáculo admirável e esplêndido da Luz, bem superior a ele, daí, invejoso e enraivecido, foi até os confins do Reino da Luz e provocou um grande tumulto, transformando os cinco elementos da matéria em cinco criaturas ou emanações suas, ou seja, conforme nos informa Santo Agostinho, «da fumaça, nasceram os animais bípedes; das trevas, as serpentes; do fogo, os quadrúpedes; da água, os animais que nadam; e do vento, as aves» (Contra ep. quam man. voc. fund., I, 28), e se lançou com seus cinco filhos contra o Pai da grandeza.

O Pai da Grandeza, por sua vez, vendo-se atacado, faz surgir, por emanação de sua própria substância, o Homem Primordial ou Originário, também chamado de Segunda Grandeza do Reino, a quem ordena que saia, com seus cinco filhos: éter, ar, luz, água e fogo, que formam sua armadura, em combate contra as forças das Trevas.

No curso do combate, o filho do Pai da Grandeza (o Homem primordial) é vencido, entregando-se aos inimigos, os arcanjos do Mal, que o fazem prisioneiro, sendo sua alma devorada pela matéria. Portanto, para o maniqueísmo, de forma panteística, o Homem Primordial é alma do Pai, ou uma parte da substância luminosa de Deus que está cativa na matéria.

\subsubsection{O segundo momento: o Espirito Vivificador}

Prisioneiro, entretanto, segundo o mito maniqueu, o Homem Primordial voltou à consciência, que havia perdido, enterrada nas Trevas junto com sua Alma, e dirigiu por sete vezes uma prece ao Pai da Grandeza. O Pai ouviu sua súplica e fez surgir dele mesmo uma segunda emanação, o Espírito Vivificador ou Amigo da Luz, ou Grande Arquiteto - Terceira Grandeza do Reino-- que com seus cinco filhos: o 'Ornamento de Esplendor' (inteligência), o «rei da honra ou Magnificência' (ciência), o ‘Rei da Glória' (reflexão), o 'Adamas-Luz' (pensamento) e o «Portador' ou 'Omóforo' (consciência)», se dirigiram à região das Trevas, baixando até os abismos do inferno profundo, descobriram o Homem Primordial absorvido pelas Trevas, e seus cinco filhos.

O Espírito Vivificador toma, então, o Homem Primordial pela mão direita e o liberta das garras e da ira do Príncipe das Trevas. Mas o Homem Primordial, ao ser salvo, deixou para trás os seus cinco filhos misturados à matéria, ou seja, parte de si mesmo, conforme narra Puech: 
O Homem Primeiro sobe, em triunfo, ao 'Paraíso da Luz'. Todavia deixa de si, ainda prisioneira das Trevas, a sua 'armadura', a sua 'alma' ou uma parte da sua 'alma', dele mesmo ${ }^{18}$.

\subsubsection{O terceiro momento: o Terceiro Enviado e Jesus}

Mas, como nem toda a Luz estava salva, o Pai da Grandeza realizou uma terceira emanação, o Terceiro Enviado ou Grande Espírito, Quarta Grandeza do Reino, que veio continuar a obra de Salvação. O Terceiro Enviado, por sua vez, adota a bela e majestosa forma feminina de Virgem da Luz, ou Mãe da Vida, que, na sua desnudez radiante, excita os desejos carnais dos arcanjos do Mal (demônios); que expelem seu esperma. Uma parte do esperma sobe em direção à luz e outra cai sobre a terra úmida, fecundando-a, dando origem às árvores e aos animais, dentre eles a primeira dupla de seres humanos: Adão e Eva.

E é, nos planos de libertação dos seres humanos, que entra em cena um quarto personagem-Jesus, quarta emanação do Pai da Grandeza ou Quinta Grandeza do Reino,

um libertador — segundo santo Agostinho-, para limpar as almas boas (animae bonae) do erro e para salvá-las do estado de mescla (commixtio) e liberá-las da servidão (Contra Fort. man., I,1).

Para o maniqueísmo, Jesus é o responsável em transmitir a Adão e Eva, e seus descendentes, a grande mensagem ou grito de libertação - a gnose - , só que, diferentemente do Cristianismo, os maniqueus o entendiam sob três figuras ou aspectos. Ou melhor, os maniqueus davam três nomes a Jesus, cada um refletindo uma dimensão ou função, mas, no fundo, tratase de uma só entidade: Jesus —uma emanação do Pai da Luz-, responsável por libertar as partículas da luz manchadas e aprisionadas na matéria desde a luta inicial entre o bem e o mal.

Assim sendo, numa primeira figura que se encontra nos escritos maniqueus, Jesus aparece com o nome de Jesus Esplendor ou Rei da Luz. Nesse primeiro aspecto, a-histórico, Jesus Esplendor é um Ser transcendente e cósmico, o criador da gnose. Ele é o Grande Pensador, ou a Grande Inteligência (o Nous) encarregado de instituir a mensagem da gnose ou o grito de libertação a toda humanidade.

Entretanto, como alerta Erik Peterson ${ }^{19}$, nesse primeiro momento, trata-se ainda de um Ser etéreo, o Nous ou Inteligência, e que não pode ser confundido com o Jesus Cristo histórico, o qual veremos logo adiante.

Nessa primeira figura, a salvação se faz pela ação direta na inteligência do homem, pelo espírito. Pois, como a alma do homem está alienada no corpo físico, que é prisão e cárcere, responsável pelo estado de inconsciência do homem, o Salvador-Jesus Esplendor, exorciza-o, revelando-se a si mesmo. Seus olhos ou sua consciência se abre e este se reconhece, salvandose a si mesmo. Ou seja, o Salvador, ao salvar o homem, salva-se a si mesmo, o que significa que há uma concretização do mito do "Salvador-Salvado".

A partir de então, o homem recebe a faculdade de reconhecer a mescla de sua condição humana, a dualidade essencial que sua condição humana implica, na qual a alma se sente aterrorizada pela matéria, origem infernal de seu corpo que é maldição. E essa tomada de consciência de sua própria condição humana traz, também, uma revelação da ciência do mundo: a origem e o destino do universo.

18 PUECH, 1995, p. 38.

19 PETERSON, 1951, p. 1963. Igualmente diz POLOTSKY, 1996, p. 74: «No maniqueísmo, o Jesus Esplendor vem acima da barreira do tempo, espaço e de todo limite histórico: a sua figura é um complemento mitológico do conceito de Nousy. 
É aí que aparece um segundo aspecto, ou sob uma segunda figura, em que Jesus é chamado por «Jesus Partibilis», ou Jesus Cruz da Luz, ou, ainda, Jesus Vivente ou Sofredor, conforme diz Puech:

Esta parte consubstancial de Deus, mesclada em todos os corpos, e curiosamente ligada à erva, às sementes, aos troncos e frutos, às árvores, sufocada pela carne, esta 'Alma Vivente' vem assimilada, com o símbolo grandioso, a personagem do Jesus Partibilis ${ }^{20}$.

Ou seja, para os maniqueus, em seu panteísmo grosseiro, a alma é parte (partículas-Jesus Partibilis) de Deus que está presente em todos os corpos materiais, esses acreditavam que é na matéria, ou neste mundo que se dá o calvário de Jesus. Por isso chamam, também, essa segunda figura de «Jesus Cruz da Luz». Ou é no mundo que assistimos, a todo momento, à paixão e à crucificação de Jesus Cruz da Luz, na matéria. Nesse momento, Jesus é uma Luz cósmica, atemporal, espalhada no ar ambiental, responsável em libertar as centelhas da Luz prisioneiras na matéria. Aqui, também, mais uma vez, Erik Peterson ${ }^{21}$ observa que ainda não se trata da figura do Jesus Cristo histórico, mas das partículas da luz espalhadas no mundo material.

Finalmente, uma terceira figura, agora histórica, é Jesus Cristo, o filho do Pai, revestido numa forma humana, que veio ao mundo, no país dos judeus.

E Mani investe na dimensão histórica de Jesus como fundamento ou justificativa de sua missão. Afinal de contas, os principais destinatários da propaganda maniquéia eram os cristãos. A esse público, pois, os maniqueus procuravam acomodar-se ao máximo. Por isso revestiam toda sua propaganda de uma roupagem cristã.

Em um dos escritos antimaniqueus agostinianos, o Contra Félix Maniqueu, por exemplo, encontramos uma amostra de como Mani fundamenta-se na pessoa de Jesus Cristo, como o profeta que o antecedeu e veio preparar sua vinda. Tese que será duramente criticada por Agostinho, conforme aparece já no inicio do debate:

Agostinho perguntou: Se leres algo deste códice que tenho em minhas mãos, a carta de Mani a que chamais 'do Fundamento', poderias reconhecê-la como tal?

Félix disse: Reconheço-a

Agostinho replicou: Toma-a tu mesmo e lê.

Havendo tomado o códice, Félix leu: 'Mani, apóstolo de Jesus Cristo, por providência de Deus Pai. Eis aqui as palavras salùtares que emanam da fonte viva e perene. Quem as ouve e primeiramente as crer, e logo cumpre o que ordena, nunca estará sujeito à morte, antes bem desfrutará de uma vida eterna e gloriosa. Com efeito, há de ser considerado justamente ditoso quem tenha sido instruído por este divino conhecimento: libertado por ele permanecerá na vida sempiterna'.

O Bispo Agostinho disse: Tens reconhecido com certeza a carta de vosso Mani?

Félix respondeu: Tenho-a reconhecido.

Agostinho: Prova-me, então, como esse Mani é apóstolo de Jesus Cristo. Pois nunca lemos seu nome no Evangelho dos apóstolos, e conhecemos quem foi ordenado para ocupar o posto de Judas, o traidor, a saber, o Santo Matias. E todo mundo sabe quem foi chamado desde o céu pela voz do Senhor: e apóstolo Paulo. Prova-me, portanto, que esse Mani é Apóstolo de Cristo, como se atreveu a escrever isto no começo de sua carta.[...] (Contra Felic. man., I, 1) ${ }^{22}$.

20 PUECH, 1995, p. 46-7.

21 PETERSON, 1951, p. 1963. O mesmo tipo de observação é feita por FREITAS, 1991, p. 61 1. Cf. também, DE LUIS, 1986. p. 55.

22 Cf. TERZI, 1937, p. 13: «Se o nome de Mani não figura no número dos Apóstolos, como diz Agostinho, ele porém estava sinceramente convicto de ser o apóstolo de Jesus Cristo». 
Como se vê, Mani se via como enviado por Cristo, tanto é assim que, segundo Agostinho, uma das principais obras de Mani, a «Carta do Fundamento», começa nos seguintes termos: «Mani, apóstolo de Jesus Cristo pela providência de Deus Pai [...]» (Contra ep. quam man. voc. fund., I, 5), por isso seus escritos e de seus seguidores estão recheados de expressões neotestamentárias.

A presença de citações neotestamentárias nos escritos maniqueus (especialmente de textos paulinos) é tão grande que alguns comentadores chegaram a denominar o maniqueísmo de «heresia paulina», principalmente aqueles que defendem ser o mesmo uma gnose cristã ${ }^{23}$.

Entretanto, se por um lado os maniqueus supervalorizavam o Novo Testamento, por outro desprezavam e ridicularizavam o Velho Testamento, conforme narra Santo Agostinho:

Costumam os maniqueus vituperar as Escrituras do Antigo Testamento, as quais ignoram; e com essa recusa, aos católicos débeis e iniciantes na fé, que não encontram como responder às suas argúcias, os enganam e zombam deles. Não há Escritura que facilmente não pode ser censurada quando a manejam aqueles que não a compreendem ( $D e$ gen. contra man., $1,1,1)^{24}$.

Mas, afinal, o que os maniqueus não aceitavam no Velho Testamento?

Nos escritos antimaniqueus, encontramos basicamente três pontos apresentados por Agostinho como problemáticos aos olhos dos maniqueus: em primeiro lugar, uma larga rejeição às explicações criacionistas da Bíblia, por meio da qual questionavam a criação do mundo por um ato livre de Deus, a partir do nada, e do homem como imagem e semelhança de Deus. Para eles, esse último ponto implicava dar a Deus uma forma antropomórfica, o que era um absurdo, pois isso significava encerrar Deus em um corpo humano, limitado e finito, conforme palavras de Agostinho:

Sobre esta questão costumam os maniqueus pôr um grito no céu com vãs e insensatos discursos, e zombam de nós, porque cremos que o homem foi feito imagem e semelhança de Deus, e atendo-se à nossa figura corporal, perguntam: acaso Deus tem nariz e dentes e barba e entranhas e todo o restante que em nós é necessário? Com razão, pois, dizem que supor tais coisas em Deus é ridículo, ainda mais, é impróprio; portanto, negam que o homem foi criado à imagem e semelhança de Deus (De gen. contra man., I, 17, 27).

Para os maniqueus, Deus é um ser corpóreo, mas ilimitado e infinito. Em segundo lugar, questionavam a conduta moral dos patriarcas, principalmente por praticarem a poligamia, que lhes parecia destituída de racionalidade científica, com aparentes contradições ético-morais, ou seja, a falta de uma explicação racional para o problema do mal, o que levaria Evans a dizer:

A maior dificuldade do maniqueísmo em ler a Biblia estava em aceitar o conteúdo do Antigo Testamento como digno de estudo sério. Não só na linguagem, mas também em sua descrição do comportamento de Abraão, Isaac, Jacó, Moisés e dos que vieram depois ${ }^{25}$.

23 A esse respeito ver PUECH, 1995, especialmente capítulo intitulado «São Paulo e os Maniqueus na Ȧsia Central», p. 141 a 154 e GARCÍA BAZÁN, 1978, especialmente tópico intitulado « Corpus Paulinum», p. 172 a 185.

24 Igualmente, começa o Sobre os Costumes da Igreja Católica e os Costumes dos Maniqueus: «Os maniqueus usam principalmente de dois artifícios para seduzir aos ingênuos e passar ante eles como mestres: um, a censura das Escrituras, que entendem ou pretendem entender muito mal; e o outro, a ficção de uma vida pura e de continência admirável» (De mor. Eccl. cath. et mor. man. I, 1, 2).

25 EVANS, 1995, p. 28-29. 
O maniqueísmo, ao contrário do Velho Testamento, como uma gnose ou ciência, ou uma religião-ciência, buscava dar uma explicação racional do universo e da vida, principalmente do problema do mal, conforme diz Puech:

No maniqueísmo a consciência é, de fato, presença iluminante do Espírito, do Nous o elemento salvador - na alma - o elemento a ser salvo. De tal modo essa confere à alma, unida aos dons intelectuais, a gnose, como, no gnosticismo, a consciência é ciência $^{26}$.

Por fim, afirmavam os maniqueus haver uma descontinuidade ou grande contradição entre o Velho e o Novo Testamentos. É o que vemos, por exemplo, no Contra Adimanto Maniqueu, quando Agostinho começa a obra, rebatendo as críticas do maniqueu Adimanto o qual asseverava haver uma contradição entre o texto do Gênesis: «No principio fez Deus o céu e a terra» (Gn. 1, 1-5), e as palavras do Apóstolo João, que diz: «O mundo foi feito por Ele e o mundo não o conheceu» $($ Jo 1,10$)$. Ao que retruca Agostinho:

No cúmulo da ignorância os maniqueus pensam que o texto da Lei se opõe ao Evangelho. Argumentam que no Gênesis está escrito ter Deus feito por si mesmo o céu, a terra e a luz, enquanto no Evangelho se lê que o mundo foi feito por Nosso Senhor Jesus Cristo (Contra Adim. man.,1).

Para os maniqueus, as duas Escrituras tinham autores diversos: enquanto o Novo Testamento tinha por autor o Senhor Deus e Pai de Nosso Senhor Jesus Cristo, o Antigo Testamento era obra de satanás, o príncipe das trevas. Conforme diz Terzi:

Os maniqueus impugnavam a concordância entre o Velho Testamento e o Novo. Defendiam que o Deus do Velho Testamento não era o Deus verdadeiro, mas o príncipe das trevas. O Novo Testamento diziam ter sido falsificado por aqueles que queriam inserir a lei dos judeus na fé cristã ${ }^{27}$.

Quanto ao Novo Testamento, apesar de interpretá-lo de forma diferente dos católicos, são poucos os pontos que os maniqueus questionavam; dentre eles, a genealogia de Jesus, que tem como conseqüências, a negação do nascimento de Jesus através da Virgem Maria. Mani, fundamentando-se em palavras do próprio Cristo, como, «Quem me recebe, recebe Aquele que me enviou» (Mt. 10, 40; Lc 10,16;Jo 13,20), «Eu não vim para cumprir a minha vontade, mas a vontade daquele que me enviou» $(J o .6,38)$ e muitas outras, afirma ser Jesus uma emanação da Luz adormecida na matéria, um Espírito Luminoso. E se Jesus não pôde ter nascimento humano, muito menos teve morte na $\mathrm{cruz}^{28}$, como diz Agostinho, citando os ensinamentos de Mani:

Pois Cristo, posto que nem nasceu, nem mostrou aos olhos humanos carne verdadeira, senão simulada, tampouco sofreu paixão, senão que a simulou (Contra ep. quam man. voc. fund., 8).

Também, discordavam dos católicos quanto à composição ou quantidade de livros do Novo Testamento, acrescentando a este certos textos apócrifos, como, por exemplo, o evangelho do

\footnotetext{
26 PUECH, 1995, p. 26.

27 TERZI, 1937, p. 65

28 Cf. O'MEARA, 1954, p. 87, diz: «Os maniqueus tinham uma repugnância toda particular em crer no nascimento virginal de Cristo e em sua morte sobre a cruz».
} 
suposto apóstolo Tomás, citado pelo bisp̉o Fausto, no Contra Fausto Maniqueu XXX, 4, onde faz referências aos «feitos dos apóstolos Pedro, André, Tomás e João».

Segundo García Bazán, os livros apócrifos, «Feitos dos Apóstolos Pedro e André», foram escritos por um tal Simão Samaritano e atribuídos aos verdadeiros Apóstolos Pedro e André. Simão Samaritano, o Mago da Samaria, conhecido como «falso apóstolo», é apontado pelos primeiros padres da Igreja católica (especialmente para São Justino Mártir e Santo Irineu de Lyon) como o primeiro gnóstico cristão. Já «Os feitos do Apóstolo João» ou «O Livro Secreto de João»; atribuído a esse apóstolo, foi escrito pelo gnóstico cristão Saturnino de Antioquia (117-138), discípulo de Menandro de Samaria, que por sua vez foi discípulo de Simão Samaritano ${ }^{29}$.

Portanto, como observa Manuel da Freitas ${ }^{30}$, apesar dos maniqueus afirmarem a historicidade de Jesus Cristo, como um dos profetas que veio preparar a vinda de Mani, o Paracleto responsável pelo processo final de libertação, para eles, Jesus Cristo era apenas uma das emanações ou manifestações corpóreas do Jesus Esplendor, que se manifestou igualmente em outros profetas, como, Seth, Enos, Henoc, Noé, Sem, Abraão, Buda e Zoroastro, tal como Cristo, vieram preparar a vinda do Parácleto final (Mani) em suas regiões. Ou seja, na doutrina maniqueísta, Cristo é:igualado à mesma categoria de Buda e Zoroastro. Todos esses enviados são uma réplica humana do Salvador $\longrightarrow$ Nous, enviados para preparar a vinda de Mani, o último dos profetas, conforme diz Robert Haardt: «Mani se entende a si mesmo como o 'selo dos profetas', como o Parácleto enviado por Jesus Cristo (Jo. 14,16,26; 15,26;16,7), como o predicador da final e universal revelação divina» ${ }^{3 !}$.

Assim, por considerar Jesus como filho direto de Deus, ou melhor, como uma das emanações de Deus na história, os maniqueus acabavam por enveredar pelo docetismo, que, segundo verbete do famoso dicionário da língua portuguesa «Aurélio», «é uma doutrina gnóstica do séc. II, segundo a qual o corpo de Cristo não era real, porém só aparente, bem como negava que Ele fosse nascido de Maria ${ }^{32}$. Assim, Mani não aceitava que Cristo fosse descendente da linhagem genealógica de Davi e, conseqüentemente, que tivesse nascido da Virgem Maria $^{33}$.

Para Mani Cristo não nasceu, nem morreu. Cristo é apenas uma emanação do espirito da Luz, um fantasma com aparềncia de homem, conforme Trapè:

Os maniqueus atalhavam as dificuldades escriturísticas: rejeitavam em bloco o Antigo Testamento. O Novo, aceitavam-no, sim, mas negando, como interpolado, tudo o que se refere ao Antigo. A genealogia de Cristo era uma destas interpolações. De resto, Cristo

29 GARCÍA BAZÁN, 1978, p. 92. Mas não só estes, em um apêndice no final de sua obra, o autor supracitado traz uma série de fragmentos de textos apócrifos usados pelos maniqueus e outras seitas gnósticas, dentre eles: Apocalipse de Santiago, Evangelho de Filipe, Evangelho de Judas, Evangelho dos Nazarenos, etc., e até um Evangelho de Maria (cf. GARCÍA BAZÁN, 1978, p. 255-340). Cf. Também, TARDIEU, [s.d], p. 50.

30 Cf. FREITAS, 1991, p. 608. Igualmente, LISSÓN, 1984, p. 869, faz o mesmo tipo de observação.

31 HAARDT, 1984, p. 420. Cf. também, PUECH, 1995, p. 79: «Cada um desses Reveladores — que são todos irmãos - parece que encarnam um só e mesmo personagem do qual Seth seria a primeira manifestação e Mani a última [...], são as emanações e no fundo as personificações do Nous».

32 FERREIRA, 1986, p. 605. Já CUNHA, 2001, p. 297, depois de afirmar ser o docetismo uma doutrina segundo a qual Cristo teria apenas a aparência e não uma realidade corporal, diz: «A heresia, que foi combatida por Clemente e Orígenes, desenvolveu-se com os nicolaitas (dizia-se que o bispo Nicoláu, de extrema pureza realizava milagres) e, posteriormente, vinculou-se ao maniqueísmo, proveniente da Pérsia, e ao montanismo, procedente da Frígia, cujas denominações derivam de seus fundadores, Mani e Monton».

33 A esse respeito, diz DI STEFANO, 1960, p. 64: « Os cristãos, para Mani, tinham feito de Cristo o criador de Satanás e o autor de suas más ações, rebaixaram Cristo ao papel de homem, fazendo dele o filho de uma mulher chamada Maria, nascido do seu sangue e da sua carne, vindo ao mundo com todas as sujeiras que acompanham o nascimenton. 
não tinha assumido um corpo verdadeiro, mas só um corpo aparente; não podia ter, por isso, uma genealogia ${ }^{34}$.

Mais do que isso, os maniqueus estendiam suas interpretações docetistas até ao corpo, à paixão, à morte e ressurreição de Cristo, ou seja, para eles, Cristo não tinha corpo, mas era um fantasma ou espírito da Luz com forma humana. Bem como não sofreu realmente a paixão, nem morreu na cruz, nem ressuscitou ${ }^{35}$. Para os maniqueus, a paixão, morte e ressurreição de Cristo são fatos históricos, mas não reais. Trata-se, pois, de uma simulatio, de um parecer, que aos olhos dos homens se mostrava como real e nesse sentido dá-se como real de fato. Posto que, para estes $\longrightarrow$ os maniqueus, como interroga santo Agostinho,

como poderiam crer que ressuscitou aquele de quem não crêem que haja morrido? Pois, como podem crer que haja morrido aquele de quem não crềem que haja tido um corpo mortal? (Contra Faust. man., XII, 4).

$\mathrm{Ou}$, ainda mais categórico, como interroga o próprio maniqueu Fausto:

Se Jesus não nasceu, como morreu? (Contra Faust. man., XXVI, 1).

Para os maniqueus, Cristo, com o objetivo de chegar aos homens mais facilmente, tomou uma carne aparente, quando, na realidade, ele é um «corpo luminoso etéreo ou espiritual um fantasma». A verdadeira paixão e crucificação de Cristo está, para os maniqueus, na mescla ou mistura da Luz na matéria, ou seja, Cristo (também chamado de Jesus Partibilis ou Cruz da Luz) encontra-se crucificado nas partículas da Luz (alma do mundo) presa ou cativa na matéria. Em síntese, os maniqueus negavam que Cristo fosse a encarnação do Verbo em um corpo humano. Pare eles, isso significava dar a Deus uma Forma antropomórfica, o que era um absurdo. Cristo não necessita de corpo humano, Ele é apenas um fantasma, um Espírito.

\section{REFERÊNCIAS}

AGUSTÍN, San. Actas del debate con Fortunato. In: Obras completas des san Agustín. Trad. Int. y notas de Pio de Luis. ed. Bilingüe. Madrid: La Editorial Catolica, 1986. (Biblioteca de Autores Cristianos, vol. XXX), p. 225-378.

-. Replica a la carta llamada «Del fundamento». In: Obras completas de san Agustín. Trad. Int. y notas de Pio de Luis. ed. Bilingüe. Madrid: La Editorial Catolica, 1986. (Biblioteca de Autores Cristianos, vol. XXX), p. 379-460.

- Actas del debate con Felix. In: Obras completas de san Agustín. Trad. Int. y notas de Pio de Luis. ed. Bilingüe. Madrid: La Editorial Catolica, 1986. (Biblioteca de Autores Cristianos, vol. XXX), p. 461-542.

-. Contra Fausto. In: Obras completas de san Agustín. Trad. Int. y notas de Pio de Luis. ed. Bilingüe. Madrid: La Editorial Catolica, 1993.(Biblioteca de Autores Cristianos, vol. $\mathrm{XXXI)}, 834 \mathrm{p}$.

\section{TRAPĖ, 1971, p. 64.}

35 Conforme vimos em nota anterior, apesar de afirmarem ser Deus um enter corpóreo, os maniqueus não aceitavam a materialidade ou encarnação de Cristo, pois isso significava torná-lo pecador, já que a matéria é por si algo mau. Para eles, Deus é um ser corpóreo, mas etéreo, infinito e ilimitado. Cf. STEINER, 1995, p. 32: «Para Mani - Cristo Jesus é um ser que não assume verdadeiramente uma corporeidade terrestre, mas vive só em um corpo aparente sobre a terra, em um corpo etéreo». 
- De la natureza del bien: contra los maniqueus. In: Obras completas de san Agustín. Trad. int. y notas de Mateo Lanseros. ed. Bilingüe. Madrid: La Editorial Catolica, 1951. (Biblioteca de Autores Cristianos, vol. III), p. 973-1047.

- De las costumbres de la Iglesia catolica y de las costumbres de los maniqueos. In: Obras completas de san Agustín. Trad. int. y notas de Teófilo Prieto. ed Bilingüe. Madrid: La Editorial Catolica, 1948.(Biblioteca de Autores Cristianos, vol. IV), p. 235-451.

- Del genesis contra los maniqueos. In: Obras completas de san Agustín. Trad. int. y notas de Balbino Martin. ed. Bilingüe. Madrid: La Editorial Catolica, 1957. (Biblioteca de Autores Cristianos, vol. XV), p. 351-498.

- Las confesiones. In: Obras completas des san Agustín. Trad. Int. y notas de Angel Custodio Vega. 3 ed. Bilingüe. Madrid: La Editorial Catolica, 1955. (Biblioteca de Autores Cristianos, vol. II), $731 \mathrm{p}$.

- Réplica a Adimanto. In: Obras completas de san Agustín. Ed. bilingue. Trad., introd. y notas de Pio de Luis. Madrid: La Editorial Catolica, 1986. (Biblioteca de Autores Cristianos, vol. XXX), $639 \mathrm{p}$.

ASMUSSEN, Jes P. Maniqueísmo. In: BLEEKER, C. Jouco; WIDENGREN, Geo (Orgs). Historia religionum: manual de historia de las religiones (I): religiones del pasado. Madrid: Ediciones Cristiandad, 1973. p. 560-589.

BARDY, Gustave. Manichéisme. In: VACANT, A.(Org.). Dictionnaire de théologie catholique. Paris: Librairie Letouzey et Ané, 1926. p. 59-71.

COSTA, Marcos Roberto Nunes. Santo Agostinho: um gênio intelectual a serviço da fé. Porto Alegre: Edipucrs, 1999. 215 p.

-.O problema do mal na polêmica antimaniquéia de Santo Agostinho. Porto Alegre: Edipucrs; Recife: UNICAP, 2002. 429 p.

-. Maniqueismo: história, filosofia e religião. Petrópolis: Vozes, 2003. 175 p.

CUNHA, L. Fernando Whitaker da. Heréticos e cismáticos (teologia e política). Revista Brasileira de Filosofia. São Paulo. vol. LI, fasc. 203. p. 295-315. Jul./set. 2001. Trimestral.

DANIEL-ROPS. O Santo dos Novos Tempos In: História da Igreja de Cristo (I): A Igreja dos apóstolos e dos mártires. Trad. de Eduardo Pinheiro. Braga: Livraria Tavares Martins, 1960.

DE LUIS, Pio. San Agustín y el maniqueísmo-introducción general a los escritos antimaniqueos. In: Obras completas de san Agustín. Trad. int. y notas de Pio de Luis. ed. Bilingüe. Madrid: La Editorial Católica, 1986. (Biblioteca de Autores Cristianos, vol. XXX), p. 3-170.

DI STEFANO, Anna Escher. Il manicheismo in s. Agostino. Padova: Casa Editrice Dott. Antonio Milano, 1960. 217 p.

EVANS, Gillian R. Agostinho sobre o mal. Trad. de João Rezende. São Paulo: Paulus, 1995. $270 \mathrm{p}$.

FERREIRA, Aurélio Buarque de Holanda. Novo dicionário da língua portuguesa. 2 ed. Rio de Janeiro: Nova Fronteira, 1986.

FREITAS, Manuel da Costa. Maniqueísmo. In: LOGOS-Enciclopédia luso-brasileira de filosofia. Lisboa/São Paulo: Verbo, 1991. Tomo 3, p. 607-613.

GARCÍA BAZÁN, Francisco. Gnosis: la esencia del dualismo gnóstico. Buenos Aires: Ediciones Casteñeda, 1978. 371 p.

HAARDT, Robert. Maniqueísmo. In: ALFARO, Juan; FONDEVILA, José M. (Org.). Sacramentum mundi: enciclopedia teológica. Barcelona: Editorial Herber, 1984. Tomo IV, p.

LISSÓN, D. Ramos. Maniqueísmo In: GRAN ENCICLOPEDIA RIALP. Madrid: Ediciones RIALP, 1984. Tomo XIV, p. 869-870.

O'MEARA, John J. La jeunesse de saint Augustin: son évolution intérieure jusqu' à 1'époque de la conversion. Trad. Jeanne Henri Marrou. Paris: Librairie Plon, 1954. 277 p.

PETERSON, Erik. Mani-manicheismo. In: ENCICLOPEDIA CATTOLICA. Roma: Città 
del Vaticano, 1951.p. 530-541.

POLOTSKY, Hans-Jacob. Il manicheismo: gnosi i salvezza tra Egito e Cina. Trad. Cllaudia Leurini. Rimini: Cerchio Iniziative Editoriali, 1996. p.

PUECH, Henri-Charles. Sul manicheismo e altri saggi. Trad. de Augusto Combra. Torino: Giulio Einaudi Editore, 1995. 463 p.

- Manichéisme In: ENCICLOPAEDIA UNIVERSALIS. Paris: Enciclopaedia Universalis France, 1990. Corpus 14. p. 436-446.

-. El maniqueísmo. In:

(Org.). Historia de las religiones (VI): las religiones en el mundo Mediterráneo y en el Oriente prójimo. Trad. de Lorea Baruti e Alberto Cardin. México/Madrid: Siglo Veintiuno Editores, 1979. p. 194-331.

-. Il manicheismo. In: (Org.). Gnosticismo e manicheismo. Trad. de Maria Novella Pierini. Roma: Editori Laterza, 1988. p. 160-277.

RIES, Julien. Mani et manichéisme In: VILLER, M.; CAVALLERA, F.; GUIBERT, J. de (Orgs.). Dictionnaire de spiritualité: ascétique et mystique; doctrine et histoire. Paris: Beauchesne, 1980. Tome X, p. 189-216.

STEINER, Rudolf. I manichei. Trad. de Iberto Bavastro. Milano: Editrice Antroposofica, $1995.59 \mathrm{p}$.

TARDIEU, Michel. O maniqueísmo. Trad. de Antônio M. Magalhães. Porto: Rés Editora, [s.d.]. $156 \mathrm{p}$.

TERZI, Carlo. Il problema del male nella polemica antimanichea di s. Agostino. Udine: Istituto delle Edizioni Accademiche, 1937. $108 \mathrm{p}$.

TRAPÈ, Agostino. S. Agostino: 1' uomo, il pastore, il mistico. Fossano: Editrice Esperienze, $1971.439 \mathrm{p}$.

VANNINI, Marco. Invito al pensiero di sant'Agostino. Milano: Mursia Editore, 1989. $200 \mathrm{p}$.

Av. João de Barros, 1205/101

Espinheiro-Recife-PE-Brasil

CEP 52021-180

E-mail: marcosc@unicap.br 